Article

\title{
Interactive Effects of Business Environment Assessment and Institutional Programs on Opportunity Entrepreneurship
}

\author{
Yongseok Jang ${ }^{1}$, Woo Jin Lee ${ }^{2, *}$ and Brandy Hadley ${ }^{3}$ (D) \\ 1 Department of Management, California State University San Bernardino, San Bernardino, CA 92407, USA; \\ yongseok.jang@csusb.edu \\ 2 Graduate School of Global Entrepreneurship, Kookmin University, Seoul 02707, Korea \\ 3 Department of Finance, Appalachian State University, Boone, NC 28608, USA; hadleybe@appstate.edu \\ * Correspondence: drlee@kookmin.ac.kr; Tel.: +82-2910-5948
}

Received: 14 June 2020; Accepted: 23 June 2020; Published: 1 July 2020

\begin{abstract}
The study of the institutional characteristics that create favorable environments for opportunity entrepreneurship is critical. We seek to determine how government programs intended to support entrepreneurship impact how potential entrepreneurs view the business environment. We evaluate the effectiveness of institutional programs and the interactions between them and market optimism. We conduct a binomial regression to evaluate the probability of opportunity entrepreneurship, given the perceived quality of the business and regulatory environments. The results indicate that both have a significant influence, while the regulatory dimensions interact with the effects of the perceived quality of the business environment. We find that individuals who have optimism regarding entrepreneurship still seek assurance of a positive regulatory environment before they act. We find that those who consider it to contain promising entrepreneurship opportunities still seek a positive regulatory climate and supportive government programs before acting. Programs that create favorable financial access can encourage entrepreneurs attracted by financial returns. Similarly, favorable government programs that ensure expansion and growth may reinforce this financial optimism. Our study also adds to the literature on institutional economics, providing evidence that effective institutional factors require productive behaviors from individuals.
\end{abstract}

Keywords: entrepreneurship; entrepreneurial environment; opportunity

\section{Introduction}

Entrepreneurship makes significant contributions to economic development in multiple ways. A systematic review conducted by Van Praag and Versloot (2007) [1] indicates that entrepreneurship contributes to economic development through employment creation, productivity growth, and innovative services and products. Additionally, using panel data collected from multiple countries, Ferreira, Fayolle, Fernandes, and Raposo (2017) [2] present empirical evidence to show a positive effect for total early-stage entrepreneurial activity on a global competitiveness index. The impact of entrepreneurship goes beyond the economic and the social; entrepreneurship effectively engages in addressing environmental issues as well [3]. The notion of "green innovation" is, therefore, an extension of the definition of entrepreneurship which is considered as a social agent that reacts to market imperfection [4]. Entrepreneurship is also considered a byproduct of institutional inefficiency and such a conceptualization is particularly relevant when it comes to issues of sustainability. In another way, innovation driven by entrepreneurs is largely called forth by governments and societies to respond to the increasing demand for rectifying environmental problems, where public 
and traditional entrepreneurs are largely found inefficient due to their heavy emphasis on and preoccupation with economic growth [5]. Acknowledging such limitations, an increasing number of governments make environmental regulations more stringent and manage programs to incentivize private entities to engage in pro-environmental behaviors [6]. The gap between environmental goals and the reality is still left largely unfilled and presents as an opportunity for entrepreneurs. Opportunity-driven entrepreneurship is a series of reactive or proactive behaviors to such demands [4].

Due to the increased recognition of entrepreneurship as a determinant of economic growth [7], the variation in rates of entrepreneurial activities across different countries has been investigated in macro-level studies. These provide an abundance of evidence that institutions play a critical role in enabling or hindering entrepreneurial activities [8-10]. These studies support the belief that the economic behavior of human agents is a product of the institutions they are subject to, as asserted by the classic institutional theory of economic growth [11].

In the context of entrepreneurship, Scott (2008) [12] proposed that the institutional environment may be understood as resting on the three pillars of regulative, cognitive, and normative institutions. They provide individuals with the incentive to engage in economic behaviors that are conducive to the growth of entrepreneurial activity. The regulatory dimension involves the institutional organization of regulations, policies, rules, and laws used to incentivize and penalize individuals' economic behaviors. For entrepreneurship, regulatory approaches are usually designed to ensure and protect the private ownership of property [13], to control the level of risk involved in new venture creation [14], and to enable entrepreneurship by improving access to critical resources [15]. However, regulatory approaches are generally considered to be a hinderance to entrepreneurial opportunity. It is widely believed that where regulation predominates, entrepreneurial opportunity is less apparent. Free markets and lower barriers to entry are thus often seen as highly desirable from an entrepreneurial perspective [16]. Counter arguments to such views contend that a lack of institutions is a source of increased uncertainty, which discourages individuals from engaging in risk-taking behaviors $[17,18]$. Another point of view attributes the benefits that come from an institutional environment to the interplay between formal and informal institutions [19], rather than the presence or number of regulations.

The significant role that institutions play in entrepreneurial activities on the country level has been studied [10], but additional work is needed to address gaps in the literature. For example, further detailed analysis is required to address the dynamics of the interactions between formal and informal institutions [20]. In addition, it is not known which types of government program are most favorable for opportunity entrepreneurship. The resulting poor level of understanding of the impacts of differing regulatory approaches could result in the failure of regulatory programs intended for use by public agents to build the formal institutions that foster opportunity entrepreneurship. This limited understanding can further cause governments to fail both in differentiating the effectiveness of individual regulatory programs and in identifying specific government programs for investment.

To develop this understanding, we test the roles of individuals, the regulatory dimensions of opportunity entrepreneurship, and their mutual interaction [21]. First, we investigate the roles that perceived opportunity and quality of government programs play in relation to opportunity entrepreneurship. Second, we seek to establish what types of government program increase opportunity entrepreneurship, examining, for instance, those that have financial resource provisions or lower barriers to entry. Finally, we examine how government programs function in relation to entrepreneurs' assessment of opportunity.

Our approach is consistent with the theory of institutional growth and the belief that the intentionality of innovative individuals toward entrepreneurship is largely influenced by the institutions they are subject to [22]. To identify what specific government programs can be used to improve institutions, we explore a range of such programs and how they interact with entrepreneurs' perception of opportunity. This approach sets this study apart, as others either consider the regulatory dimension to be a sub-class of institutions or ignore heterogeneity among the different government programs 
that promote entrepreneurship. To the best of our knowledge, ours is the first study to consider entrepreneurs' own opportunity perception in relation to the role of institutions.

In addition to this notable differentiating factor, we believe that this study makes additional contributions as well. First, our study gives a comparative perspective of the roles of the individual's discovery and the regulatory dimensions. The results of our assessment indicate that both have a significant influence on opportunity entrepreneurship, which is aligned with existing knowledge on the indirect role of institutions. Second, this study produces new empirical insight into the interaction between individuals and regulatory dimensions. We find that individuals who exhibit optimism regarding entrepreneurship also seek the assurance of a positive regulatory environment. Our study is relevant to the literature on institutional economics, adding evidence that effective institutional factors require productive behaviors from individuals. This further reinforces the view that institutions do not have automatic effects on their own, as proposed by traditional growth theory.

In the next section, we present an overview of institutional theory to explain how our analysis is defined and anchored in the conceptual framework. We then present a set of testable hypotheses. Using these, the main effect of entrepreneurs' opportunity perceptions is considered before the effect of the regulatory dimension. We present evidence of a stronger effect of entrepreneurs' opportunity perception on opportunity entrepreneurship, implying that the regulatory dimension plays a complementary role. We then test the impact of the interaction between entrepreneurs' discovery processes and interventions by government program. We conclude the paper by discussing the implications that our study holds for the existing literature.

\section{Materials and Methods (Theory and Hypotheses)}

\subsection{Institutional Theory}

Institutional theorists contend that institutions help define norms in the business environment and drive or constrain the economic behavior of individuals [23], which, therefore, may have significant consequences on long-term economic development [24]. Institutions are part of the social rules of the game, where individuals are provided with the incentives and penalties that motivate their behavior in a particular direction [24]. According to traditional economic theory, institutions may be formal or informal [11,24]. Among formal institutions are constitutions, regulations, contracts, economic freedom [25], political corruption [26,27], procedures, and the size and capability of the government [28]. On the other hand, norms, social recognition, values, and culture are examples of informal institutions. Formal and informal institutions interact and complement each other; however, among other differences, formal institutions can change within a short period of time, but informal institutions take time to change [29].

Effective formal institutions include the protection of private property $[21,28,30]$, taxation, social safety nets, labor policies, competition policies, trade policies, and capital market regulations [31]. These formal institutions may reduce transaction costs, thus enhancing market efficiency [32]. Well-defined rules are likely to disincentivize individuals to engage in banned opportunism actions, while increasing the levels of social capital [33]. Often times, formal institutions are designed to achieve a specific goal, one of which is the promotion of innovative behavior to solve environmental issues [34]. The institutional incentives also create pressure for firms to respond, the magnitude of which often exceeds those of customers [35]. Poorly designed institutions, by contrast, can result in counterproductive behavior, reducing trust and the incentive to invest in productive activities [36]. Social capital, individualism, power distance, and risk-taking culture are examples of effective informal institutions [37-40]. The categories of formal and informal can be refined into regulative, normative, and cultural-cognitive institutions [41]. Cultural and social elements are significant factors for the success of entrepreneurial ventures [42,43].

Aidis, Estrin, and Mickiewicz (2008) [20] find that institutions can either promote or constrain the entrepreneurial actions of individuals. In the literature, it is found that entrepreneurs may need to 
explore a range of strategic approaches to better adapt to their unique business environment, which is defined by varied institutional factors. Aldrich and Fiol (1994) [23] illustrate the interaction between individual entrepreneurs' assets and the industrial context with their finding that new businesses are more vulnerable when their industry is in its formative stage due to new ventures' lack of social and cognitive legitimacy. Peng and Heath (1996) [44] echoed the literature by presenting the strategic approaches that are uniquely relevant to different institutional contexts, such as the planned economies of the countries of the former sphere of influence of the Soviet Union. They found that informal agreements and interpersonal trust were highly significant, although they are not considered to be critical in the Western business context.

Institutions encourage and discourage individuals from certain economic choices, including the choice to enter into entrepreneurship. Manolova, Eunni, and Gyoshev (2008) [45] find meaningful indicators that values, traditions, and institutional heritage have a significant impact on the promotion of entrepreneurship. Startup intention also appears to be influenced by institutions. Liñán, Urbano, and Guerrero (2011) [46] find that college students in Spain exhibit differences in entrepreneurial intention, and such differences can be explained by the varied social valuation of entrepreneurship in different regions. Similarly, the social payoff structure and informal institutions encourage individuals to consider entrepreneurship to be a favorable career option [47].

The literature of the classic institutional theory generally focuses on inquiries at the macro level, focusing heavily on the function of institutions [48-50]. These studies are based on the deterministic view according to which institutions are seen as the single most influential factor that shapes the context for entrepreneurship. When institutions are treated as antecedents of entrepreneurial activities [22], organizational development at any stage and any entrepreneurial activities are thus regarded solely as a product of a suitable environment [12].

As noted, formal institutions and governments require further study, and both suffer from a lack of practical insight in relation to their role in opportunity entrepreneurship. Formal institutions are explored in the literature, but the majority of studies have examined the impact of social systems on entrepreneurial activities, rather than the impact of regulatory dimensions on opportunity entrepreneurship. For example, Chowdhury, Audretsch, and Belitski (2015) [27] investigated how political corruption affects entrepreneurial activities. Van Stel, Storey, and Thurik (2007) [51] examined the relationship between labor policy and business ownership, pursuing the same line of logic. Sobel (2008) [7] and Li and Zhara (2012) [52] present a correlation between formal institutions and the investment of venture capital, as well as the reinvestment of profits [53]. Although these results are certainly interesting, political systems and structures may provide only a limited understanding of the context and how it shapes business activities.

It is necessary to take into account the impacts of individuals' discovery processes and government programs before the interaction effects of the regulatory environment are considered. We expect to see direct effects of the discovery processes of entrepreneurs on opportunity entrepreneurship, as entrepreneurial action toward opportunity-based entrepreneurship follows individuals' opportunity detection. In the following section, we develop testable hypotheses in relation to these considerations.

\subsection{Hypotheses}

\subsubsection{Direct Effects of Individuals' Discovery Processes}

The adequate arrangement of institutions plays a critical role in fostering entrepreneurial activities at the country level, but individuals' actions serve as a precursor in many economic activities. Individuals are largely considered to be agents in opportunity entrepreneurship [54], and they engage in discovery by linking prior knowledge, entrepreneurial intentions, and alertness to opportunity [55]. Both the willingness and capability for engaging in entrepreneurial activities are needed [56,57]. Additionally, the ability to tolerate uncertainty is a key precursor for entrepreneurial behaviors [58]. Following the premise that entrepreneurship is largely a product of a subtle interplay between 
individual characteristics of individuals and opportunity, it is critical to understand individuals' perceptions of entrepreneurial opportunity. Adequate institutional arrangements, therefore, effectively foster entrepreneurial activities as they increase incentives and reduce restrictions for individuals in the business environment [25].

Therefore, we consider that individuals' opportunity assessment includes the evaluation of three dimensions. First, the market situation is evaluated to determine whether the environment is favorable. Favorable markets are characterized by either weak supply or strong demand, as market imbalance is a precondition for novel entrepreneurial action. Second, the entrepreneurial environment is evaluated. This describes the degree to which starting a new venture is considered favorable [59]. Again, a precondition to starting a new venture is that it will provide advantages over other career options, such as employment opportunities. Third, the financial side must be considered. This includes evaluating the profitability and financing of the new venture. For example, in a situation where the capital market is accessible at lower interest rates than usual, this can greatly influence financial optimism. These three dimensions lead us to our first hypothesis:

Hypothesis 1 (H1). In entrepreneurs' assessment of opportunity entrepreneurship, the evaluation of the business environment (the market situation, the entrepreneurial environment, and financial expectations) has a direct effect.

\subsubsection{Direct Effects of Government Programs}

Governments operate a range of programs to support businesses. One approach is to make it easier to start a new business, which is assessed in terms of the discouraging effects that complicated regulatory procedures have on entrepreneurship [60,61]. These programs often focus on lowering the barriers to new firm formation $[62,63]$ by creating an accelerated process of starting a business, including lowering the number of processes required, by removing unnecessary permitting and licensing [51]. Ho and Wong (2007) [64] find that excessive barriers to entry discourage opportunity entrepreneurship by increasing transaction costs. Because startup costs for early-stage firms are a critical factor, empirical studies have found a strong correlation between the activities of small business and low entry costs [62].

The supply-side approach is taken to make resources available. Often, this is in the form of access to the critical resource of capital. Based on the belief that entrepreneurship can be fostered if access to funding is provided [65], governments operate programs that provide financial support or special advantages to new startups $[64,66]$. Governments have many options available for providing direct access to financial resources, but capital is usually provided through banks to ensure efficiency. To ease the liability of newness [67], lowering capital requirements, fostering investment companies, and creating credit guarantee schemes are effective means of aiding entrepreneurs with their resource needs [68].

A third approach would be to create a favorable set of regulations to ensure the growth and expansion of business. This approach is based on the belief that entrepreneurs could be incentivized by the potential to grow and harvest the profits they obtain from the ventures they begin. Other options the government may have in this regard are making it easy to hire and fire [69,70], creating favorable and reasonable tax systems and making the exit process as simple as possible [51].

Finally, a fourth approach would be for governments to provide general non-financing support to entrepreneurs. This route is based on the belief that increasing the information available may encourage individuals to pursue entrepreneurship. Entrepreneurs do in fact often need training to acquire the necessary skillsets, such as how to start a business, how to prepare and plan a business, and how to conduct market analysis. A common and popular example of this type of program is one where networking opportunities are provided.

In general, we expect that a positive assessment in these regulatory dimensions may have a direct effect on opportunity-driven entrepreneurship. In particular, given the nature of opportunity entrepreneurship, which is based on individuals' perception of opportunities and their likelihood 
of significant economic growth, opportunity-driven entrepreneurs might use a different system of prioritization when evaluating government programs. One hypothesis here is that they would prioritize and seek assurance of financial return, measured by decreased startup costs, increased access to capital, and greater likelihood of growing the venture once it was begun. On the other hand, non-finance programs may have little to no impact, given the nature of the high potential growth. Alternatively, we expect to see a positive and significant role of the first three regulatory approaches on opportunity entrepreneurship. Our hypothesis below derives from this discussion.

Hypothesis 2 (H2). As entrepreneurs consider opportunity entrepreneurship, their evaluation of the regulatory environment (aiding with venture startups, availability and access to financial resources, and programs to aid with expansion and growth of ventures) have a direct effect on their willingness to act. However, a regulatory environment that provides only general, non-financing support may not have any direct effect on opportunity entrepreneurship.

\subsubsection{Moderating Effects of Government Programs}

Because government programs require individuals to be willing to act if they are to be effective, programs that strengthen this willingness are important. For example, opportunity-driven entrepreneurship may be sensitive to the availability of government programs that guarantee harvesting potential or make the process easier. However, this may mean that government programs targeting ease and cost reduction in startups might not be the primary concern of individuals who prioritize profit and aspire to build a highly profitable venture.

This example of the interdependence between institutional actions and individual motivations on success highlights the necessity to examine the interactive relations between individuals' actions and the regulatory environment. Specifically, the regulatory environment may moderate the effects of the assessment on the business environment. In other words, entrepreneurs who are assessing the business environment for opportunity-based entrepreneurship may also wish to consider the regulatory environment before making the decision to go into business. In our case, opportunity-driven entrepreneurship could be incentivized differently due to its specific nature. As opportunity-driven entrepreneurship is directed toward high-growth activities, entrepreneurs' decision-making focuses on whether the perceived opportunity offsets the value of maintaining the status quo [30,71]. Although the hierarchy of value might vary, the pursuit of a high-growth venture primarily concerns financial returns [30]. Often, entrepreneurs discover new niches due to their industry experience, enabled by an in-depth understanding of the sector [72]. In these cases, industry-specific knowledge may offset the value of entrepreneurial knowledge and the ability to effectively assess opportunities, found ventures, and leverage social networks [73].

In response to these considerations, we hypothesize that entrepreneurs who consider the business environment to be in their favor are further encouraged by government programs that make the financing easier, less expensive, and more accessible. Government regulatory approaches intended to protect property rights would help encourage individuals who are willing to risk seeking greater financial returns [28]. In the same vein, opportunity-driven entrepreneurship is encouraged by government programs that aid growth and the expansion of businesses. On the other hand, we hypothesize that government programs that provide general support for entrepreneurs may not have significant power to moderate individuals' assessments.

Hypothesis 3 (H3). The regulatory environment related to financial resources and returns (availability and access to financial resources and programs to aid with expansion and growth of ventures) may moderate the effect of the assessment of the business environment. However, this assessment may not be moderated by government programs designed to provide general support (aid with the process of starting a venture or general, non-financing support). 


\subsection{Empirical Analysis}

\subsubsection{Data}

We utilize a comprehensive database that monitors, tracks, and collects individuals' activities related to entrepreneurship, called the Global Entrepreneurship Trend Report (GETR). This database has been maintained by the Venture Small Business Division, in collaboration with the Korea Entrepreneurship Foundation, since 2015. The initial round of data collection included 10 major countries and focused on how entrepreneurship is viewed. Data on careers, personal and professional backgrounds, types of entrepreneurship, entrepreneurial activities engaged in by stage, perceived assessments of the business and regulatory environments for entrepreneurship, perceptions of the cultural atmosphere toward entrepreneurship, intention to start a venture, and entrepreneurial orientation are included in the survey.

This survey was expanded in 2016. The database now provides comprehensive information collected from entrepreneurs in 20 countries. The countries were chosen to represent a range of regions and with consideration for a diversity of GDP levels. Included are countries from Asia (South Korea, Japan, China, India, Indonesia, and Singapore), Europe (the UK, Germany, Russia, Denmark, and Finland), the Middle East (Turkey, UAE, and Israel), and Africa (South Africa and Egypt), three countries in the Americas (the USA, Brazil, and Chile), and one in Oceania (Australia).

The survey sampled a minimum of 2000 respondents per country for a total sample size of 40355 valid respondents. The primary sample group was extrapolated using stratified sampling based on the population statistics for each country. The secondary sample group was extrapolated through quota sampling based on gender and age groups as percentages of the entire population, for a sampling error of $\pm 2.19 \%$ at a $95 \%$ confidence level. A 7-point Likert scale was used for the responses, and these values have been converted to a 100-point scale for better readability and grouped into negative $(1,2$, and 3 points), neutral (4 points), and positive (5, 6 , and 7 points) response categories.

\subsubsection{Sampling Strategy}

We created a subset of 3203 respondents by focusing on a group of countries with a relatively homogeneous economic context, namely, only countries included in the Organization for Economic Co-operation and Development (OECD), as it enables a comprehensive set of controls on macro-variables such as per capita income and stage of economic development. This approach allows us to control for the impact of the level of development on entrepreneurial behavior [41]. Included in our subset are two countries in Asia (South Korea, Japan), four in Europe (the UK, Germany, Denmark, and Finland), two in the Middle East (Turkey, Israel), two in the Americas (the USA, Chile), and one in Oceania (Australia).

\subsubsection{Measurement}

In this study, we utilize the 2016 GETR to capture how individual entrepreneurs assess the business environment in the three dimensions of market, financial, and entrepreneurial quality. We use the qualities of four different types of government approaches to examine how the programs interact with individuals' assessment of the business environment.

Dependent variable. We rely on individuals' indications in favor of opportunity-driven entrepreneurship. In the GETR, respondents indicated whether their intended business would be driven by opportunity. The information is captured in a binary format, with opportunity-driven entrepreneurship denoted as one.

Independent variables. We develop three constructs to measure how entrepreneurs assess the business environment for entrepreneurship. First, our market assessment construct is operationalized using two survey questions that indicate respondents' perception of the potential of doing business overseas, as well as perceived potential to commercialize a technology. Identifying the opportunity to do business in a foreign market indicates respondents' optimism regarding the market, reflecting 
that respondents have found an untapped opportunity overseas and believe the domestic and foreign markets can support their endeavor. A firm that commercializes a technology can harvest profits from it, which often encourages more opportunity-driven entrepreneurial activities, indicative of a better business environment for entrepreneurship. Leveraging key resources is central to opportunity detection and evaluation, according to Hitt et al. (2011) [74].

Entrepreneurial assessment, our second construct, reflects the challenges that entrepreneurs face as they go through the process of beginning a new venture. Our measurement utilizes entrepreneurs' assessment of the extent to which their business can survive once it is initiated and how effective government regulation is at simplifying its initiation.

The third dimension of the business environment that we consider is the assessment of the financial climate. Here, we consider two factors. First, we investigate how optimistic entrepreneurs are about financing from the private sector. Second, we incorporate how certain they are that they will be able to harvest profits from the venture once they start the business.

Moderating variables. Four types of government programs are observed to form our regulatory dimensions. The first type of government program that we consider is the possibility of entry into an entrepreneurial path. We combine information on how entrepreneurs view the effectiveness of government-funded incubator programs and how accessible they are. We also measure how effective (versus how bureaucratic) public agents are as a proxy for the quality of civil service. The second element we consider is access to credit. Entrepreneurs provide an assessment of how accessible government finance is. The third element relates to general support for entrepreneurship, such as how effective small business development center(SBDC) trainings are. We consider such training to be general, non-financing support that the government provides to help entrepreneurs. Finally, entrepreneurs shared their assessment of potential expansion and growth. Our construct is obtained from a combination of these assessments on tax policy and government policy to protect market positions, such as anti-trust legislation, and policy support for doing business overseas.

Control variables. Socio-demographic characteristics are important factors to control for [75]. Age [76], sex, and formal education are controlled for because innovative entrepreneurial activity has been shown to be impacted by these. Gender is considered, as females tend to demonstrate lower rates of entrepreneurship [77,78]. Formal education appears to influence startup intention and the likelihood of engaging in entrepreneurial activities $[79,80]$. The level of education is captured in six categories, ordered from lowest to highest. The level of current income is captured by the degree to which respondents are satisfied with their current income. The underlying assumption is that higher dissatisfaction would be more likely to lead to an entrepreneurial career. Entrepreneurial experience is controlled for on the basis that individuals with more startup experience would consider such careers to be less risky, leading to a greater likelihood of pursuing an entrepreneurial career [81]. Entrepreneurial career experience is measured by the number of new ventures begun by the respondent. We also control for whether respondents plan to take over their family businesses. This is unlikely to be an example of true opportunity-driven entrepreneurship if individuals take over a family business. A binary variable identifies whether individuals took over a family business or not. Finally, the current size of the business is also controlled for, as large operations may discourage owners from pursuing new, opportunity-driven ventures, as these are often high-risk enterprises. Size is measured by the number of employees. Table 1 presents the descriptions of the variables used in this research.

\subsection{Empirical Analysis}

We employ binomial logistic regression to estimate the probability of an event given the binary nature of the dependent variable. As is widely known, this technique assumes that the probability of an event is a function of its explanatory variables, which in this case is a combination of two sets of independent variables: entrepreneurs' assessments of the business environment and the quality of the regulatory dimension. Logistic regression is used because this technique allows for the analysis of a mixture of categorical and continuous variables. Unlike any other discriminant analyses that 
require strict assumptions, logistic regressions are relatively more likely to meet multivariate normality and equal variance requirements and are much more robust. In contrast with the linear regression technique, the nonlinear nature of the logistic transformation is based on iterative measurements to find the most likely estimates for the coefficients, while the process of estimating the coefficients is still similar to linear regression. In other words, logistic regression maximizes the likelihood that an event occurs, instead of minimizing the squared deviations. A notable warning for the adequate use of the technique is that the method requires a proper sample size so that each group has a minimum of five observations. Besides, as chi-square statistics are sensitive to sample size, the technique may find small differences statistically significant when the sample size becomes large [82]. In our model, the ordinal predictors (Likert scale items) are considered as continuous ones as they are unanimously seven. As Lubke and Muthen (2004) [83] and Glass, Peckham, and Sanders (1972) [84] indicated, parametric tests may use Likert scale item validly depending on contingencies. As they are not nominal underordered categories, there is no fear of losing any information.

Table 1. Description of variables.

\begin{tabular}{|c|c|c|c|}
\hline Category & Construct & Description & Count \\
\hline DV & $\begin{array}{c}\text { Opportunity } \\
\text { Entrepreneurship }\end{array}$ & & 3203 \\
\hline \multirow{3}{*}{ IV } & Market assessment & $\begin{array}{l}\text { Assessment of chance of doing business } \\
\text { in a foreign market } \\
\text { How efficient it is to obtain a license in technology }\end{array}$ & 1476 \\
\hline & Entrepreneurial assessment & $\begin{array}{c}\text { Assessment of the chance of survival after launching } \\
\text { a new venture } \\
\text { Effectiveness of launching a new venture }\end{array}$ & 3203 \\
\hline & Financial assessment & $\begin{array}{l}\text { Effectiveness of harvesting through IPO and M\&A } \\
\text { Financing from angel investor or VC }\end{array}$ & 3203 \\
\hline \multirow{4}{*}{$\begin{array}{l}\text { Moderating (regulatory } \\
\text { dimensions) }\end{array}$} & Entry & $\begin{array}{l}\text { Access to government-funded incubator } \\
\text { Effectiveness of government-funded incubator programs } \\
\text { Effectiveness of public agencies }\end{array}$ & 3203 \\
\hline & Access to credit & Effectiveness of government financing & 3203 \\
\hline & General non-financing support & $\begin{array}{c}\text { SBDC (effectiveness) } \\
\text { Policy }\end{array}$ & 3203 \\
\hline & Expansion and growth & $\begin{array}{l}\text { Effectiveness on anti-monopoly } \\
\text { Policy support for doing business in a foreign market }\end{array}$ & 3203 \\
\hline \multirow{7}{*}{ Control } & \multirow{3}{*}{ Demographic } & Age (year of birth) & 3203 \\
\hline & & Sex & 3203 \\
\hline & & Formal educational attainment & 3203 \\
\hline & \multirow{4}{*}{ Socio-economic } & Satisfaction with current income & 3203 \\
\hline & & Number of new ventures started & 3203 \\
\hline & & Succeeded a family business & 3203 \\
\hline & & Number of employees at current business & 3203 \\
\hline
\end{tabular}

\section{Results}

Table 2 provides the Pearson correlation matrix and Table 3 gives the results of the binomial regression technique, using robust standard errors to consider potential heteroskedasticity. Countries are controlled for in all models, but the coefficients are not presented here.

In our base model, our control variables are generally found to be significant. One interesting observation is that the size of current operations seems to have a positive influence, implying that individuals in charge of larger organization are still inclined toward opportunity entrepreneurship, which is attended to with higher levels of risk. This may be attributed to the level of confidence gained from operating a larger business. Family business background is significant in this model, but it is nonsignificant in other findings. The overall model is significant because the log pseudo-likelihood statistic is -1538.3 , with a $p$-value of 0.000 . 
Table 2. Pairwise correlation.

\begin{tabular}{|c|c|c|c|c|c|c|c|c|c|c|c|c|c|c|c|}
\hline Variable $^{1}$ & Mean & SD & 1 & 2 & 3 & 4 & 5 & 6 & 7 & 8 & 9 & 10 & 11 & 12 & 13 \\
\hline DV & 0.604 & 0.489 & 1.0000 & & & & & & & & & & & & \\
\hline Age & 3.78 & 1.240 & $-0.0939 *$ & 1.0000 & & & & & & & & & & & \\
\hline Ent Experience & 1.857 & 3.144 & 0.0259 & 0.0231 & 1.0000 & & & & & & & & & & \\
\hline Education & 4.27 & 1.06 & $0.0672 *$ & 0.0276 & $0.0307^{*}$ & 1.0000 & & & & & & & & & \\
\hline Current Income & 4.17 & 1.38 & 0.2694 * & $-0.1170 *$ & $0.0695 *$ & 0.1393 * & 1.0000 & & & & & & & & \\
\hline $\begin{array}{l}\text { Current } \\
\text { Operation }\end{array}$ & 3.642 & 2.10 & 0.1790 * & $-0.1759 *$ & $0.0470 *$ & $0.1087^{*}$ & 0.3145 * & 1.0000 & & & & & & & \\
\hline $\begin{array}{l}\text { Market } \\
\text { assessment }\end{array}$ & 3.10 & 1.74 & 0.2613 * & -0.2148 * & 0.1430 * & $0.1570^{*}$ & 0.4190 * & $0.2666^{*}$ & 1.0000 & & & & & & \\
\hline $\begin{array}{l}\text { Entrepreneurial } \\
\text { assessment }\end{array}$ & 3.73 & 1.45 & 0.2324 * & -0.0850 * & 0.0739 * & $0.0622 *$ & 0.2829 * & $0.0987 *$ & $0.5578^{*}$ & 1.0000 & & & & & \\
\hline $\begin{array}{l}\text { Financial } \\
\text { Assessment }\end{array}$ & 3.34 & 1.46 & $0.2708^{*}$ & -0.2450 * & 0.1054 * & 0.0569 * & 0.3491 * & $0.2262 *$ & 0.6686 * & $0.5705^{*}$ & 1.000 & & & & \\
\hline M1 Entry & 2.15 & 1.83 & $0.2689 *$ & $-0.2806^{*}$ & 0.1604 * & $0.0552 *$ & 0.3800 * & $0.2608^{*}$ & $0.6574^{*}$ & 0.4149 * & $0.564^{*}$ & 1.0000 & & & \\
\hline $\begin{array}{l}\text { M2 Access to } \\
\text { Credit }\end{array}$ & 3.33 & 1.61 & 0.2328 * & $-0.2307^{*}$ & $0.0943 *$ & 0.0571 * & 0.3163 * & $0.2010 *$ & $0.6033^{*}$ & $0.5064^{*}$ & $0.726^{*}$ & $0.5552 *$ & 1.0000 & & \\
\hline M3 General & 4.09 & 1.69 & $0.1682 *$ & $-0.1056^{*}$ & $0.0363^{*}$ & 0.0570 * & 0.2437 * & 0.1299 * & 0.4181 * & $0.4265 *$ & $0.418^{*}$ & $0.3939 *$ & $0.4836^{*}$ & 1.0000 & \\
\hline $\begin{array}{l}\text { M4 Expansion/ } \\
\text { Growth }\end{array}$ & 2.98 & 1.40 & 0.2958 * & $-0.1959 *$ & $0.1344^{*}$ & $0.1103 *$ & 0.3851 * & $0.1993 *$ & 0.6646 * & 0.5599 * & 0.612 * & 0.6309 * & 0.5741 * & 0.4577 * & 1.0000 \\
\hline
\end{tabular}

${ }^{1}$ Dummy variables are not included. * Statistically significant scores.

Table 3. Logit results.

\begin{tabular}{|c|c|c|c|c|c|c|}
\hline Category & Variables & Base model & Model 1 & Model 2 & Model 3 & Model 4 \\
\hline DV & Opportunity entrepreneurship & $\mathrm{OE}$ & $\mathrm{OE}$ & $\mathrm{OE}$ & $\mathrm{OE}$ & $\mathrm{OE}$ \\
\hline \multirow{7}{*}{ Control } & Age & $\begin{array}{l}-0.004 \\
(0.038) \\
\end{array}$ & $\begin{array}{c}0.151 \\
(0.065) \\
\end{array}$ & $\begin{array}{c}0.074 \\
(0.040)^{* *}\end{array}$ & $\begin{array}{c}0.163 \\
(0.065)^{* *} \\
\end{array}$ & $\begin{array}{c}0.166 \\
(0.065)+ \\
\end{array}$ \\
\hline & Sex & $0.050(0.091)$ & $\begin{array}{l}-0.162 \\
(0.153)\end{array}$ & $\begin{array}{c}0.003 \\
(0.093)\end{array}$ & $\begin{array}{l}-0.188 \\
(0.155)\end{array}$ & $\begin{array}{l}-0.173 \\
(0.154)\end{array}$ \\
\hline & Ent experience & $\begin{array}{l}-0.000 \\
(0.013)\end{array}$ & $\begin{array}{l}-0.010 \\
(0.019)\end{array}$ & $\begin{array}{l}-0.018 \\
(0.013)\end{array}$ & $\begin{array}{l}-0.013 \\
(0.016)\end{array}$ & $\begin{array}{l}-0.014 \\
(0.017)\end{array}$ \\
\hline & Education & $\begin{array}{c}0.196 \\
(0.050)^{* * *}\end{array}$ & $\begin{array}{c}0.186 \\
(0.073)^{* *}\end{array}$ & $\begin{array}{c}0.196 \\
(0.052)^{* * *} \\
\end{array}$ & $\begin{array}{c}0.194 \\
(0.075)^{* *}\end{array}$ & $\begin{array}{c}0.209 \\
(0.074) \text { ** }\end{array}$ \\
\hline & Current income & $\begin{array}{c}0.295 \\
(0.036)^{* * *}\end{array}$ & $\begin{array}{c}0.264 \\
(0.061)^{* * *}\end{array}$ & $\begin{array}{c}0.210 \\
(0.039)^{* * *}\end{array}$ & $\begin{array}{c}0.246 \\
(0.063)^{* * *}\end{array}$ & $\begin{array}{c}0.246 \\
(0.063)^{* * *}\end{array}$ \\
\hline & Family business background & $\begin{array}{c}0.538 \\
(0.120)^{* * *}\end{array}$ & $\begin{array}{l}-0.111 \\
(0.185)\end{array}$ & $\begin{array}{c}0.014 \\
(0.133) \\
\end{array}$ & $\begin{array}{l}-0.249 \\
(0.192) \\
\end{array}$ & $\begin{array}{l}-0.263 \\
(0.195) \\
\end{array}$ \\
\hline & Current operation & $\begin{array}{c}0.095 \\
(0.022)^{* * *}\end{array}$ & $\begin{array}{c}0.131 \\
(0.037)^{* * *}\end{array}$ & $\begin{array}{c}0.073 \\
(0.023)^{* *}\end{array}$ & $\begin{array}{c}0.124 \\
(0.037)^{* *}\end{array}$ & $\begin{array}{c}0.126 \\
(0.038)^{* * *}\end{array}$ \\
\hline \multirow{3}{*}{ IV } & Market assessment & & $\begin{array}{c}0.151 \\
(0.062)^{* *}\end{array}$ & & $\begin{array}{c}0.047 \\
(0.067)\end{array}$ & $\begin{array}{c}0.217 \\
(0.197)\end{array}$ \\
\hline & Entrepreneurial assessment & & $\begin{array}{c}0.056 \\
(0.065)\end{array}$ & & & \\
\hline & Financial assessment & & $\begin{array}{c}0.291 \\
(0.070)^{* * *} \\
\end{array}$ & & $\begin{array}{c}0.157 \\
(0.083)+ \\
\end{array}$ & $\begin{array}{l}-0.334 \\
(0.229) \\
\end{array}$ \\
\hline \multirow{4}{*}{ Moderating } & M1 Entry & & & $\begin{array}{c}0.158 \\
(0.037)^{* * *} \\
\end{array}$ & $\begin{array}{c}0.135 \\
(0.052) * * \\
\end{array}$ & $\begin{array}{c}0.448 \\
(0.186)+ \\
\end{array}$ \\
\hline & M2 Access to credit & & & $\begin{array}{c}0.112 \\
(0.039)^{* * *}\end{array}$ & $\begin{array}{c}0.036 \\
(0.068)\end{array}$ & $\begin{array}{l}-0.186 \\
(0.195)\end{array}$ \\
\hline & M3 General & & & $\begin{array}{l}-0.035 \\
(0.033) \\
\end{array}$ & & \\
\hline & M4 Expansion/growth & & & $\begin{array}{c}0.244 \\
(0.049)^{* * *}\end{array}$ & $\begin{array}{c}0.243 \\
(0.077)^{* *}\end{array}$ & $\begin{array}{l}-0.074 \\
(0.209)\end{array}$ \\
\hline \multirow{8}{*}{ Interaction } & Market Assessment $\times$ M1 Entry & & & & & $\begin{array}{l}-0.033 \\
(0.045)\end{array}$ \\
\hline & $\begin{array}{c}\text { Market assessment } \times \text { M2 Access to } \\
\text { credit }\end{array}$ & & & & & $\begin{array}{l}-0.022 \\
(0.049)\end{array}$ \\
\hline & Market assessment $\times$ M3 General & & & & & \\
\hline & $\begin{array}{c}\text { Market assessment } \times \text { M4 } \\
\text { Expansion/growth }\end{array}$ & & & & & $\begin{array}{l}-0.006 \\
(0.054)\end{array}$ \\
\hline & $\begin{array}{l}\text { Entrepreneurial assessment } \times \text { M1 } \\
\text { Entry }\end{array}$ & & & & & \\
\hline & $\begin{array}{l}\text { Entrepreneurial assessment } \times \text { M2 } \\
\text { Access to credit }\end{array}$ & & & & & \\
\hline & $\begin{array}{c}\text { Entrepreneurial assessment } \\
\times \text { M3General }\end{array}$ & & & & & \\
\hline & $\begin{array}{l}\text { Entrepreneurial assessment } \times \text { M4 } \\
\text { Expansion/growth }\end{array}$ & & & & & \\
\hline
\end{tabular}


Table 3. Cont.

\begin{tabular}{|c|c|c|c|c|c|c|}
\hline Category & Variables & Base model & Model 1 & Model 2 & Model 3 & Model 4 \\
\hline & Financial assessment $\times$ M1 Entry & & & & & $\begin{array}{l}-0.069 \\
(0.046)\end{array}$ \\
\hline & $\begin{array}{c}\text { Financial assessment } \times \mathrm{M} 2 \text { Access } \\
\text { to credit }\end{array}$ & & & & & $\begin{array}{c}0.089 \\
(0.053)+\end{array}$ \\
\hline & Financial assessment $\times$ M3 General & & & & & \\
\hline & $\begin{array}{l}\text { Financial assessment } \times \text { M4 } \\
\text { Expansion/growth }\end{array}$ & & & & & $\begin{array}{c}0.110 \\
(0.063)+\end{array}$ \\
\hline Cons & & $\begin{array}{l}-2.526 \\
(0.326)^{* * *} \\
\end{array}$ & $\begin{array}{c}-3.935 \\
(0.525)^{* * *}\end{array}$ & $\begin{array}{c}-3.41 \\
(0.360)^{* * *}\end{array}$ & $\begin{array}{c}-4.14 \\
(0.540)^{* * *}\end{array}$ & $\begin{array}{c}-3.259 \\
(0.715)^{* * *}\end{array}$ \\
\hline $\mathrm{N}$ & & 2621 & 1277 & 2621 & 1277 & 1277 \\
\hline $\begin{array}{l}\text { Log } \\
\text { pseudo-likelihood }\end{array}$ & & -1538.3 & -634.1 & -1476.5 & -622.4 & -616 \\
\hline Pseudo R2 & & 0.1142 & 0.162 & 0.1498 & 0.1775 & 0.1859 \\
\hline AIC & & 3112.592 & 1310.21 & 2997.008 & 1290.755 & 1290.03 \\
\hline BIC & & 3218.275 & 1418.40 & 3126.177 & 1409.257 & 1439.45 \\
\hline
\end{tabular}

We begin by estimating the main effect of individuals' assessment of the business context in Model 1: the pseudo R-squared increases from 0.1142 to 0.162 . This model partially supports Hypothesis 1 , as it identifies significant positive coefficients for Market assessment $(\beta=0.151, p<0.01)$ and Financial assessment $(\beta=0.291, p<0.01)$. However, we do not observe a significant relationship with Entrepreneurial assessment. This finding may mean that individuals who pursue opportunity entrepreneurship are less concerned with how easy or difficult it would be to start a venture. More importantly, they focus on whether the market is ready and the extent to which it is feasible to finance the venture.

In Model 2, we incorporate our four constructs for government programs (Entry, Access to credit, General non-financing, and Expansion/growth) to evaluate the direct effects of the regulatory dimensions. The pseudo R-squared decreases slightly from 0.162 to 0.1498 , but the model remains significant, with a log pseudo likelihood statistic of 1476.5 and a $p$-value of 0.000 . As predicted by Hypothesis 2, we find significant, positive direct impacts for most government programs. Those programs that support the initiation of starting a venture, those that provide and increase availability and access to financial resources, and those that make expansion and growth easier are found to be effective. However, also consistent with Hypothesis 2, we failed to observe a significant role for general non-financing of government programs in opportunity entrepreneurship. Recall that we treat business context as an explanatory variable, while institutional context is treated as a moderating variable. We find some significant main effects from our institutional constructs in Model 2; Model 1 seems to be a better model for explaining opportunity entrepreneurship based on lower Akaike (AIC) and Schwarz (BIC) criteria for Model 1 (AIC-1310.21, BIC-1418.40) compared to those for Model 2 (AIC-2997.008, BIC-3126.177).

Model 3 presents a full specification for testing the direct effects of the independent variables, but only for those found significant in the previous two models. The pseudo R-squared increases from 0.1498 to 0.1775 . In this model, only three constructs, Financial assessment $(\beta=0.157, p<0.10)$, Entry $(\beta=0.135, p<0.01)$ and Expansion/growth $(\beta=0.243, p<0.01)$ remain significant. Market assessment and Access to credit are nonsignificant. In Model 3, AIC (1290.755) and BIC (1409.257) are even lower than in Model 1, which implies that accounting for the role of regulatory dimensions helps explain opportunity entrepreneurship.

In Model 4, we test interactions between the explanatory variables and the moderating constructs using only the significant variables identified in Models 1 and 2. The pseudo R-squared increases from 0.1775 (Model 3) to 0.1859 , indicating that Model 4 better explains the likelihood of individuals pursuing opportunity entrepreneurship and is by far the strongest model. The control variables Education, Current income, and Size of current operation remain significant with similar or stronger statistical significance. We find partial support for Hypothesis 3, as the model includes two sets of constructs 
that have significant interactions. We observe positive and statistically significant coefficients for the interactions between Financial assessment and Access to credit $(\beta=0.089, p<0.10)$, as well as between Financial assessment and Expansion/growth $(\beta=0.110, p<0.10)$. However, when controlling for the interactions, the variables themselves cease to be significant. This indicates that the positive relation between the likelihood of pursuing opportunity entrepreneurship and Financial assessment is dependent on and strengthened by Access to credit and the outlook for Expansion/growth. Another notable observation is that the magnitude of the direct effect of the entry programs increases and is larger than any other model, showing a statistically significant difference. Model 4 appears to be the best model in terms of having the smallest AIC (1290.03), which signifies that it is important and valuable to account for the moderating effects of regulatory dimensions in explaining opportunity entrepreneurship.

\section{Discussion}

The purpose of this paper is to examine the relations between individuals' assessments and regulatory institutions and the impact of these relations on opportunity-driven entrepreneurship. First, we evaluate the standalone effects of individuals' assessments of the business environment as well as the perceived quality of government programs on opportunity entrepreneurship. We find that government programs may encourage the pursuit of perceived opportunities, but individuals' discovery processes are important motivators as well. Specifically, we observe positive effects from programs that lower entry barriers, provide better access to government credit, and support expansion and growth. However, we do not observe a significant impact of general, non-financing support programs. Our findings indicate that governments can foster opportunity entrepreneurship in several meaningful ways. Governments can improve access to capital by utilizing public financial resources, lowering barriers to entry for new ventures, and continuing to support entrepreneurs beyond the initial start-up phase through expansion programs. On the other hand, entrepreneurs do not consider general, non-financing government programs helpful in their consideration of opportunity entrepreneurship.

Next, we analyze the interactive relations between entrepreneurs' discovery processes and the impact of government programs. We identify a positive and significant interaction between financial optimism and access to government credit. It is not surprising that entrepreneurs with high expectations of receiving financial rewards would also be concerned with sources of financing. Government programs that create favorable financial access can encourage entrepreneurs who are attracted by financial returns. We also observe a positive and significant interaction between favorable government programs for expansion and growth on the one hand and financial optimism on the other. In other words, entrepreneurs with financial optimism also care about the support for expanding and growing their venture, once it is created. A favorable set of government programs to ensure expansion and growth of the venture appear to reinforce this financial optimism. This finding is consistent with the existing understanding of entrepreneurship, where fear of failure is understood to be a key factor that discourages entrepreneurship [41].

This research contributes to the existing literature in several ways. First, it presents a comparative perspective for the roles of individuals' views of entrepreneurial opportunity and how these views interact with regulatory dimensions. Our tests find that both the assessments of individuals and the institutional environment have a significant influence on opportunity entrepreneurship. However, our results illustrate that government programs have a complementary rather than primary role. This finding is aligned with and helps to clarify existing knowledge on the indirect role of institutions. Multiple studies have found institutions to be helpful for understanding entrepreneurial activity and assessing how entrepreneurs make decision [22,85]. This study demonstrates that individuals' discovery processes have a stronger influence than regulatory institutions. Recognizing individuals as differentiating agents possessing different capabilities, cognitive processes, and intentions is consistent with recently developed understandings of the relations between institutions and individuals [86].

Second, this study provides novel empirical insights into the interaction between individuals and regulatory dimensions. We find that individuals with optimism regarding entrepreneurship also 
seek to be assured of a positive regulatory environment before they act. Our observation provides evidence that government programs that effectively aid entrepreneurs with entry may also encourage them to pursue opportunity entrepreneurship. Note that we predicted that entrepreneurs driven by opportunity often leverage assets developed in previous work experience; their assets include a professional network. The reality might be that the skillsets necessary to start a venture might not be available within the set of people an entrepreneur already knows. Another observation is that entrepreneurs appear to place significant value on access to credit through government funding and on regulatory aid for expansion and growth. This is consistent with existing knowledge that identifies financial resources as a key factor for the creation and growth of new business [87]. Providing effective financial policy may develop the creation of a positive national culture that may have long-term, positive effects on entrepreneurship [88]. We believe these findings entail practical insights for policy makers who are considering targeted approaches to help opportunity-based entrepreneurship. As is widely accepted [89], a policy approach requires the use of a specifically targeted method to optimally provide for high-growth ventures.

This analysis was made possible through the use of a unique dataset that provides information on how individuals assess the entrepreneurial context and the regulatory context. Existing studies that rely on macro-level data suffer from an inability to capture how individuals see the institutional environment. For example, GEM data provide individual-level information, including total entrepreneurial activities, but no environmental context is given [2]. The number of entrepreneurial activities an entrepreneur is involved in does provide a strong objective basis for measurement, but there is no way of evaluating how the institutional environment interacts with the market environment, as perceived by individual entrepreneurs. Another widely used database, that of the World Bank, only provides objective data, but it would be greatly beneficial if it also measured how objective facts, such as the number of procedures, are perceived and assessed by entrepreneurs. Thanks to the availability of GETR, this study can explain which government programs matter to individuals by bridging two types of information, subjective assessments of the business context and the regulatory environment. Davidsson and Wiklund (2007) [90] indicate that both micro- and macro-level factors exist behind the intention of entrepreneurship. This study supports this view by indicating how a sophisticated regulatory approach can increase certainty for entrepreneurs considering an opportunity.

Our study also adds to the literature on institutional economics. We provide evidence that institutional factors are only effective if they are conducive to the contributing behaviors of individuals. This further reinforces the view that institutions do not have automatic effects by themselves, as proposed by traditional growth theory. Our findings provide evidence that regulatory dimensions have a weaker effect on opportunity entrepreneurship than individuals do; however, they also enhance individuals' optimism regarding the potential success of opportunity entrepreneurship. We believe that this finding is consistent with the work of Rodrik (2003) [91], who assigned only an indirect role to institutions in explaining economic performance at a macro level. This was later echoed by Aparicio et al. (2016) [92] and contradicts the traditional growth model, which assumes an automatic influence of institutions and suggests that institutions require productive behavior, such as entrepreneurial activities, to be effective. For scholars of institutionalism, this finding suggests that the impact of individuals should be reconsidered and that how institutions work with individuals should be examined. It also implies that the literature could profitably explore which institutions can help individuals perceive and evaluate business opportunities.

As adequate policy provisions are critical for business creation and survival, policy implications can be drawn from the current study to help public institutions [93]. First, governments may develop policy guidelines for different purposes; one for aiding growth-oriented new ventures, and the other for aiding necessity-based new ventures. Based on the findings of the study, growth-oriented new ventures, namely opportunity-driven entrepreneurship, may benefit from better access to financial resources and a promising environment for growth and expansion. Infrastructure to provide non-financing, general entrepreneurial support can be used as complementary support system, instead of primary ones. 
Depending on the priority of countries, governments may apply relevant resource allocation strategies to help entrepreneurs, while they achieve their policy goals more effectively. For example, countries may use the expansion of financial access to entrepreneurs to give priority to opportunity-driven entrepreneurs when they are trying to undergo serious economic development processes to achieve high growth. Developing an international trade office might encourage entrepreneurs to pursue growth-oriented ventures in a foreign market. The legal system ensuring fair competition is another effective approach to drive aggressive economic growth. On the other hand, increased investment in a program like SBDC(Small Business Development Center) or Incubator might not be much efficient.

A closing remark should be made on the current challenge the entire global community has to be responsible for: the environmental crisis. As widely acknowledged, the call for action to change its course is loud, yet no substantial actions have followed. The pragmatic implication of this paper, therefore, can be extended and one can argue that government efficiency could be improved depending on how effectively designed they are and whether they are relevant to an entrepreneur's perception of the assessment of opportunity in the market of sustainability. It is only matter of applying the implication to a specific context, where entrepreneurial solutions are needed to improve natural surroundings.

\section{Limitations and Future Research}

The limitations include the fact that this study relies on subjective assessments. While the data are insightful regarding individuals' responses to particular government programs, our study assumes that individuals have an adequate level of understanding of government programs. In reality, we know that this is rarely the case. Individuals often make invalid assessments because information about government programs is imperfectly shared. There is also the possibility that any given individual's assessments could be biased for unobserved reasons. We were able to utilize objective measures of program quality using World Bank data, but doing so would require the assumption of optimal education and advertising of entrepreneurship programs, which is often far from reality. Future research projects should examine potential differences between the perspectives of policy designers and those of professional entrepreneurs.

Finally, this study does not capture the varied effects of industry heterogeneity. We account for entrepreneurial experience to control for how entrepreneurs feel about the process of launching an enterprise; however, we were not able to control for industry experience, thus failing to control for industry-specific knowledge. Human capital theory clearly indicates that entrepreneurial career choice is influenced by the level of industry-specific knowledge that the entrepreneur has [80,94]. If entrepreneurs benefit from industry-specific knowledge, which government programs are the most helpful? Do particular industries benefit differently from certain government programs? Future studies are needed to answer these questions.

Author Contributions: Conceptualized the research design, Y.J.; methodology, W.J.L. and Y.J.; software, W.J.L.; validation, W.J.L. and Y.J.; formal analysis, W.J.L. and Y.J.; resources, W.J.L.; data curation, Y.J. and W.J.L.; writing-original draft preparation, W.J.L. and Y.J.; writing-review and editing, B.H.; visualization, B.H.; supervision, W.J.L.; project administration, Y.J. All authors have read and agreed to the published version of the manuscript.

Funding: This research received no external funding.

Conflicts of Interest: The authors declare no conflict of interest.

\section{References}

1. Van Praag, C.M.; Versloot, P.H. What is the value of entrepreneurship? A review of recent research. Small Bus. Econ. 2007, 29, 351-382. [CrossRef]

2. Ferreira, J.J.; Fayolle, A.; Fernandes, C.; Raposo, M. Effects of Schumpeterian and Kirznerian entrepreneurship on economic growth: Panel data evidence. Entrep. Reg. Dev. 2017, 29, 27-50. [CrossRef] 
3. Cohen, B.; Winn, M.I. Market imperfections, opportunity and sustainable entrepreneurship. J. Bus. Ventur. 2007, 22, 29-49. [CrossRef]

4. Galindo-Martín, M.A.; Castaño-Martínez, M.S.; Méndez-Picazo, M.T. The Relationship between Green Innovation, Social Entrepreneurship, and Sustainable Development. Sustainability 2020, 12, 4467. [CrossRef]

5. Acs, Z.J.; Boardman, M.C.; McNeely, C.L. The social value of productive entrepreneurship. Small Bus. Econ. 2013, 40, 785-796. [CrossRef]

6. Demirel, P.; Iatridis, K.; Kesidou, E. The impact of regulatory complexity upon self-regulation: Evidence from the adoption and certification of environmental management systems. J. Environ. Manag. 2018, 207, 80-91. [CrossRef]

7. Sobel, R.S. Testing Baumol: Institutional quality and the productivity of entrepreneurship. J. Bus. Ventur. 2008, 23, 641-655. [CrossRef]

8. Belitski, M.; Chowdhury, F.; Desai, S. Taxes, corruption, and entry. Small Bus. Econ. 2016, 47, $201-216$. [CrossRef]

9. Minh, T.T.; Hjortsø, C.N. How Institutions Influence SME Innovation and Networking Practices: The Case of Vietnamese Agribusiness. J. Small Bus. Manag. 2015, 53, 209-228. [CrossRef]

10. Stenholm, P.; Acs, Z.J.; Wuebker, R. Exploring country-level institutional arrangements on the rate and type of entrepreneurial activity. J. Bus. Ventur. 2013, 28, 176-193. [CrossRef]

11. North, D.C. Understanding the Process of Economic Change; Academic Foundation: Haryana, India, 2006.

12. Scott, W.R. Institutions and Organizations: Ideas and Interests; SAGE: Newbury Park, CA, USA, 2008.

13. Verheul, I.; Wennekers, S.; Audretsch, D.; Thurik, R. An eclectic theory of entrepreneurship: Policies, institutions and culture. In Entrepreneurship: Determinants and Policy in a European-US Comparison; Springer: Boston, MA, USA, 2002; pp. 11-81.

14. Baumol, W.J.; Strom, R.J. Entrepreneurship and economic growth. Strateg. Entrep. J. 2007, 1, $233-237$. [CrossRef]

15. Busenitz, L.W.; Gomez, C.; Spencer, J.W. Country institutional profiles: Unlocking entrepreneurial phenomena. Acad. Manag. J. 2000, 43, 994-1003.

16. El-Namaki, M.S.S. Encouraging entrepreneurs in developing countries. Long Range Plan. 1988, 21, 98-106. [CrossRef]

17. Aidis, R. Institutional barriers to small-and medium-sized enterprise operations in transition countries. Small Bus. Econ. 2005, 25, 305-317. [CrossRef]

18. Boettke, P.J.; Coyne, C.J. Entrepreneurship and development: Cause or consequence? Adv. Austrian Econ. 2003, 6, 67-87.

19. Fuentelsaz, L.; González, C.; Maicas, J.P. Formal institutions and opportunity entrepreneurship. The contingent role of informal institutions. Brq Bus. Res. Q. 2019, 22, 5-24. [CrossRef]

20. Aidis, R.; Estrin, S.; Mickiewicz, T. Institutions and entrepreneurship development in Russia: A comparative perspective. J. Bus. Ventur. 2008, 23, 656-672. [CrossRef]

21. Williamson, C.R.; Mathers, R.L. Economic freedom, culture, and growth. Public Choice 2011, 148, $313-335$. [CrossRef]

22. Bruton, G.D.; Ahlstrom, D.; Li, H.L. Institutional theory and entrepreneurship: Where are we now and where do we need to move in the future? Entrep. Theory Pract. 2010, 34, 421-440. [CrossRef]

23. Aldrich, H.E.; Fiol, C.M. Fools rush in? The institutional context of industry creation. Acad. Manag. Rev. 1994, 19, 645-670. [CrossRef]

24. North, D.C. Institutions, Institutional Change and Economic Performance; Cambridge University Press: Cambridge, UK, 1990.

25. McMullen, J.S.; Bagby, D.R.; Palich, L.E. Economic freedom and the motivation to engage in entrepreneurial action. Entrep. Theory Pract. 2008, 32, 875-895. [CrossRef]

26. Anokhin, S.; Schulze, W.S. Entrepreneurship, innovation, and corruption. J. Bus. Ventur. 2009, 24, 465-476. [CrossRef]

27. Chowdhury, F.; Audretsch, D.B.; Belitski, M. Does corruption matter for international entrepreneurship? Int. Entrep. Manag. J. 2015, 11, 959-980. [CrossRef]

28. Estrin, S.; Korosteleva, J.; Mickiewicz, T. Which institutions encourage entrepreneurial growth aspirations? J. Bus. Ventur. 2013, 28, 564-580. [CrossRef] 
29. Williamson, O.E. The new institutional economics: Taking stock, looking ahead. J. Econ. Lit. 2000, 38, 595-613. [CrossRef]

30. Bowen, H.P.; De Clercq, D. Institutional context and the allocation of entrepreneurial effort. J. Int. Bus. Stud. 2008, 39, 747-767. [CrossRef]

31. Bjørnskov, C.; Foss, N. How strategic entrepreneurship and the institutional context drive economic growth. Strateg. Entrep. J. 2013, 7, 50-69. [CrossRef]

32. Djankov, S.; La Porta, R.; Lopez-de-Silanes, F.; Shleifer, A. The regulation of entry. Q. J. Econ. 2002, 117, 1-37. [CrossRef]

33. Boettke, P.J.; Coyne, C.J. Context matters: Institutions and entrepreneurship. Found. Trends Entrep. 2009, 5, 135-209. [CrossRef]

34. Berrone, P.; Fosfuri, A.; Gelabert, L.; Gomez-Mejia, L.R. Necessity as the mother of 'green' inventions: Institutional pressures and environmental innovations. Strateg. Manag. J. 2013, 34, 891-909. [CrossRef]

35. Llach, J.; Alonso-Almeida, M.D.M.; García-Castellví, A.; Bagur-Femenias, L. A fresh approach to context influence, development and performance in environmental management. Bus. Strategy Environ. 2015, 24, 855-872. [CrossRef]

36. Knowles, S.; Weatherston, C. Informal Institutions and Cross-Country Income Differences (No. 06/06); Credit Research Paper: Nottingham, UK, 2006.

37. Hechavarria, D.M.; Reynolds, P.D. Cultural norms \& business start-ups: The impact of national values on opportunity and necessity entrepreneurs. Int. Entrep. Manag. J. 2009, 5, 417.

38. Mueller, S.L.; Thomas, A.S. Culture and entrepreneurial potential: A nine country study of locus of control and innovativeness. J. Bus. Ventur. 2001, 16, 51-75. [CrossRef]

39. Taylor, M.Z.; Wilson, S. Does culture still matter? The effects of individualism on national innovation rates. J. Bus. Ventur. 2012, 27, 234-247. [CrossRef]

40. Urbano, D.; Aparicio, S.; Audretsch, D. Twenty-five years of research on institutions, entrepreneurship, and economic growth: What has been learned? Small Bus. Econ. 2019, 53, 21-49. [CrossRef]

41. Urbano, D.; Alvarez, C. Institutional dimensions and entrepreneurial activity: An international study. Small Bus. Econ. 2014, 42, 703-716. [CrossRef]

42. Levie, J.; Hunt, S. Culture, institutions and new business activity: Evidence from global entrepreneurship monitor. In Frontiers of Entrepreneurship Research; Babson College: Babson Park, MA, USA, 2004; pp. 519-533.

43. Park, S.H.; Luo, Y. Guanxi and organizational dynamics: Organizational networking in Chinese firms. Strateg. Manag. J. 2001, 22, 455-477. [CrossRef]

44. Peng, M.W.; Heath, P.S. The growth of the firm in planned economies in transition: Institutions, organizations, and strategic choice. Acad. Manag. Rev. 1996, 21, 492-528. [CrossRef]

45. Manolova, T.S.; Eunni, R.V.; Gyoshev, B.S. Institutional environments for entrepreneurship: Evidence from emerging economies in Eastern Europe. Entrep. Theory Pract. 2008, 32, 203-218. [CrossRef]

46. Liñán, F.; Urbano, D.; Guerrero, M. Regional variations in entrepreneurial cognitions: Start-up intentions of university students in Spain. Entrep. Reg. Dev. 2011, 23, 187-215. [CrossRef]

47. Baumol, W.J. Entrepreneurship: Productive, unproductive, and destructive. J. Bus. Ventur. 1996, 11, 3-22. [CrossRef]

48. Arshed, N.; Carter, S.; Mason, C. The ineffectiveness of entrepreneurship policy: Is policy formulation to blame? Small Bus. Econ. 2014, 43, 639-659. [CrossRef]

49. Bennett, R. SME policy support in Britain since the 1990s: What have we learnt? Environ. Plan. C Gov. Policy 2008, 26, 375-397. [CrossRef]

50. Mole, K.F.; Hart, M.; Roper, S.; Saal, D.S. Broader or deeper? Exploring the most effective intervention profile for public small business support. Environ. Plan. A 2011, 43, 87-105. [CrossRef]

51. Van Stel, A.; Storey, D.J.; Thurik, A.R. The effect of business regulations on nascent and young business entrepreneurship. Small Bus. Econ. 2007, 28, 171-186. [CrossRef]

52. Li, Y.; Zahra, S.A. Formal institutions, culture, and venture capital activity: A cross-country analysis. J. Bus. Ventur. 2012, 27, 95-111. [CrossRef]

53. Johnson, S.; McMillan, J.; Woodruff, C. Property rights and finance. Am. Econ. Rev. 2002, 92, 1335-1356. [CrossRef]

54. Shane, S.A. A General Theory of Entrepreneurship: The Individual-Opportunity Nexus; Edward Elgar Publishing: Northampton, MA, USA, 2003. 
55. Alvarez, S.A.; Barney, J.B. Discovery and creation: Alternative theories of entrepreneurial action. Strateg. Entrep. J. 2007, 1, 11-26. [CrossRef]

56. Krueger, N.F., Jr.; Reilly, M.D.; Carsrud, A.L. Competing models of entrepreneurial intentions. J. Bus. Ventur. 2000, 15, 411-432. [CrossRef]

57. McMullen, J.S.; Shepherd, D.A. Entrepreneurial action and the role of uncertainty in the theory of the entrepreneur. Acad. Manag. Rev. 2006, 31, 132-152. [CrossRef]

58. Kunkel, J.H. Values and behavior in economic development. Econ. Dev. Cult. Chang. 1965, 4, $257-277$. [CrossRef]

59. Bruno, A.V.; Tyebjee, T.T. The environment for entrepreneurship. In Encyclopedia of Entrepreneurship; Prentice-Hall: Englewood Cliffs, NJ, USA, 1982; pp. 288-315.

60. Begley, T.M.; Tan, W.L.; Schoch, H. Politico-economic factors associated with interest in starting a business: A multi-country study. Entrep. Theory Pract. 2005, 29, 35-55. [CrossRef]

61. Dana, L.P. Evaluating Policies Promoting Entrepreneurship-A Cross- Cultural Comparison of Entrepreneurship Case Study: Singapore and Malaysia. J. Small Bus. Entrep. 1987, 4, 36-41. [CrossRef]

62. Ayyagari, M.; Demirgüç-Kunt, A.; Beck, T. Small and Medium Enterprises across the Globe: A New Database; The World Bank: Washington, DC, USA, 2003.

63. Klapper, L.; Laeven, L.; Rajan, R. Entry regulation as a barrier to entrepreneurship. J. Financ. Econ. 2006, 82, 591-629. [CrossRef]

64. Ho, Y.; Wong, P. Financing, regulatory costs and entrepreneurial propensity. Small Bus. Econ. 2007, 28, 187-204. [CrossRef]

65. Holmes, R.M., Jr.; Miller, T.; Hitt, M.A.; Salmador, M.P. The interrelationships among informal institutions, formal institutions, and inward foreign direct investment. J. Manag. 2013, 39, 531-566. [CrossRef]

66. Spencer, J.W.; Gómez, C. The relationship among national institutional structures, economic factors, and domestic entrepreneurial activity: A multicountry study. J. Bus. Res. 2004, 57, 1098-1107. [CrossRef]

67. Stinchcombe, A.L. Social structure and organizations. Handb. Organ. 1965, 7, 142-193.

68. Van Gelderen, M.; Thurik, R.; Bosma, N. Success and risk factors in the pre-startup phase. Small Bus. Econ. 2006, 26, 319-335. [CrossRef]

69. Goltz, S.; Buche, M.W.; Pathak, S. Political empowerment, rule of law, and women's entry into entrepreneurship. J. Small Bus. Manag. 2015, 53, 605-626. [CrossRef]

70. Stephen, F.; Urbano, D.; van Hemmen, S. The responsiveness of entrepreneurs to working time regulations. Small Bus. Econ. 2009, 32, 259-276. [CrossRef]

71. Wennekers, S.; Van Wennekers, A.; Thurik, R.; Reynolds, P. Nascent entrepreneurship and the level of economic development. Small Bus. Econ. 2005, 24, 293-309. [CrossRef]

72. Reynolds, P.D.; Camp, S.M.; Bygrave, W.D.; Autio, E.; Hay, M. Global Entrepreneurship Monitor Gem 2001 Summary Report; London Business School and Babson College: Babson Park, MA, USA; London, UK, 2002.

73. Marvel, M.R.; Lumpkin, G.T. Technology entrepreneurs' human capital and its effects on innovation radicalness. Entrep. Theory Pract. 2007, 31, 807-828. [CrossRef]

74. Hitt, M.A.; Ireland, R.D.; Sirmon, D.G.; Trahms, C.A. Strategic entrepreneurship: Creating value for individuals, organizations, and society. Acad. Manag. Perspect. 2011, 25, 57-75.

75. Arenius, P.; Minniti, M. Perceptual variables and nascent entrepreneurship. Small Bus. Econ. 2005, 24, 233-247. [CrossRef]

76. Mitchell, R.K.; Busenitz, L.; Lant, T.; McDougall, P.P.; Morse, E.A.; Smith, J.B. Toward a theory of entrepreneurial cognition: Rethinking the people side of entrepreneurship research. Entrep. Theory Pract. 2002, 27, 93-104. [CrossRef]

77. Langowitz, N.; Minniti, M. The entrepreneurial propensity of women. Entrep. Theory Pract. 2007, 31, 341-364. [CrossRef]

78. Blanchflower, D.G. Self-employment: More may not be better (No. w10286); National Bureau of Economic Research: Cambridge, UK, 2004.

79. Jang, Y. Modeling student entrepreneurship: A longitudinal study. J. Entrep. Educ. 2013, 16, 93.

80. Jang, Y. Founders' human capital and the intensity of open innovation for new technology-based firms. In Proceedings of the United States Association for Small Business and Entrepreneurship Conference ( $p$. WWW1); United States Association for Small Business and Entrepreneurship: Tampa, FL, USA, 2015. 
81. Jang, Y.; Hadley, B.; Lee, W.J. Inward Technology Licensing, Financial Slack, and Internal Innovation in New Technology-Based Firms Located in Isolated Areas. J. Asian Financ. Econ. Bus. (Jafeb) 2019, 6, 173-181. [CrossRef]

82. Hair, J.F.; Black, W.C.; Babin, B.J.; Anderson, R.E.; Tatham, R.L. Multivariate Data Analysis; Prentice hall: Upper Saddle River, NJ, USA, 1998; Volume 5, pp. 207-219.

83. Lubke, G.H.; Muthén, B.O. Applying multigroup confirmatory factor models for continuous outcomes to Likert scale data complicates meaningful group comparisons. Struct. Equ. Modeling 2004, 11, 514-534. [CrossRef]

84. Glass, G.V.; Peckham, P.D.; Sanders, J.R. Consequences of failure to meet assumptions underlying the fixed effects analyses of variance and covariance. Rev. Educ. Res. 1972, 42, 237-288. [CrossRef]

85. Bradley, S.W.; Klein, P. Institutions, economic freedom, and entrepreneurship: The contribution of management scholarship. Acad. Manag. Perspect. 2016, 30, 211-221. [CrossRef]

86. Veciana, J.M.; Urbano, D. The institutional approach to entrepreneurship research. Introduction. Int. Entrep. Manag. J. 2008, 4, 365-379. [CrossRef]

87. Rajan, R.G.; Zingales, L. Financial Dependence and Growth (No. w5758); National Bureau of Economic Research: Cambridge, UK, 1996.

88. Autio, E.; Pathak, S.; Wennberg, K. Consequences of cultural practices for entrepreneurial behaviors. J. Int. Bus. Stud. 2013, 44, 334-362. [CrossRef]

89. Shane, S. Why encouraging more people to become entrepreneurs is bad public policy. Small Bus. Econ. 2009, 33, 141-149. [CrossRef]

90. Davidsson, P.; Wiklund, J. Levels of analysis in entrepreneurship research: Current research practice and suggestions for the future. In Entrepreneurship; Springer: Berlin/Heidelberg, Germany, 2007; pp. 245-265.

91. Rodrik, D. (Ed.) In Search of Prosperity: Analytic Narratives on Economic Growth; Princeton University Press: Princeton, NJ, USA, 2003.

92. Aparicio, S.; Urbano, D.; Audretsch, D. Institutional factors, opportunity entrepreneurship and economic growth: Panel data evidence. Technol. Forecast. Soc. Chang. 2016, 102, 45-61. [CrossRef]

93. Coduras, A.; Urbano, D.; Rojas, A.; Martínez, S. The relationship between University Support to entrepreneurship with entrepreneurial activity in Spain: A gem data based analysis. Int. Adv. Econ. Res. 2008, 14, 395-406. [CrossRef]

94. Jang, Y. Does open innovation help new technology-based firms, located in isolated areas? In Proceedings of the Academy of Management Annual Conference; Academy of Management: Briarcliff Manor, NY, USA, 2014; p. 17430.

(C) 2020 by the authors. Licensee MDPI, Basel, Switzerland. This article is an open access article distributed under the terms and conditions of the Creative Commons Attribution (CC BY) license (http://creativecommons.org/licenses/by/4.0/). 